\title{
Ефективність застосування мезенхімальних стовбурових клітин, одержаних з жирової тканини, при гонартрозі II стадії
}

\section{Л.А. Маммадов}

Вінницький національний медичний університет ім. М.І. Пирогова, Вінниця, Україна

\begin{abstract}
Анотація. Мета: оцінити функціональні результати та клінічну ефективність застосування мезенхімальних стовбурових клітин, одержаних 3 жирової тканини, при деформуючому остеоартрозі ІІ ст. протягом 12-місячного періоду спостереження. Об'єкт і методи дослідження. Обстежено 10 пацієнтів із деформуючим остеоартрозом колінного суглоба II ст.: 6 (60,0\%) чоловіків та 4 (40,0\%) жінки,

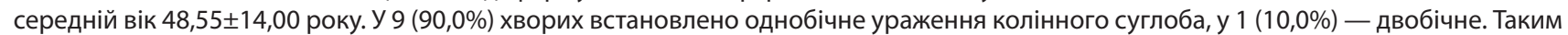
чином, проаналізовано результати обстеження 11 колінних суглобів. Лікування гонартрозу здійснювали шляхом внутрішньосуглобового введення мезенхімальних стовбурових клітин, одержаних з жирової тканини, з використанням технології Lipogems ${ }^{\circledR}$ («Lipogems International SpA», Італія) згідно з рекомендованою методикою. Клінічні результати оцінювали до лікування та через 12 міс після процедури. Функціональний стан колінного суглоба оцінювали з використанням шкали KOOS (Knee Injury and Osteoarthritis Outcome Score). Статистичний аналіз виконували з використанням програм «Microsoft Excel 2019» та «StatSoft STATISTICA 10». Peзультати. У віддалений період після використання мезенхімальних стовбурових клітин, одержаних з жирової тканини, у пацієнтів із гонартрозом II ст. отримано позитивну динаміку за всіма категоріями оцінювання функціонального стану колінних суглобів: «Симптоми» $(p=0,00005)$, «Біль» $(p=0,0002)$, «Функція, повсякденне життя» $(p=0,00007)$, «Функція, спорт та активний відпочинок» ( «Якість життя» (p=0,00006). Висновок. Протягом 12-місячного періоду спостереження доведено високу клінічну ефективність застосування мезенхімальних стовбурових клітин, одержаних з жирової тканини, при деформуючому остеоартрозі ІІ ст.

Ключові слова: деформуючий остеоартроз, колінний суглоб, мезенхімальні стовбурові клітини, жирова тканина.
\end{abstract}

\section{Вступ}

Деформуючий остеоартроз колінного суглоба (КС) вважають найбільш поширеним захворюванням опорно-рухового апарату людини та однією з провідних причин інвалідності в світі [1]. Незважаючи на широкий варіатив доступних методів консервативного та хірургічного лікування, частота дегенеративнодистрофічних захворювань суглобів залишається високою, крім того, фіксують щорічне зростання цих показників.

Одним із найбільш сучасних та актуальних напрямків в лікуванні дегенеративно-дистрофічних захворювань суглобів $\epsilon$ використання мезенхімальних стовбурових клітин (МСК). Відомо, що стовбурові клітини виділяють велику кількість біологічно активних речовин, що прискорюють метаболізм, стимулюють ангіогенез та володіють здатністю до проліферації та диференціації в інші типи клітин. Доведеною $є$ здатність МСК до хондрогенної диференціації шляхом експресії колагену ІІ типу та кислих мукополісахаридів, які $\epsilon$ характерними для гіалінового хряща. Ключова роль використання мультипотентних МСК при деформуючому остеоартрозі полягає в індукції процесів регенерації хрящової тканини [2-4].

Серед джерел МСК найбільш оптимальним $€$ жирова тканина завдяки великій кількості та відносній доступності порівняно з іншими. Саме стромально-васкулярна фракція жирової тканини $є$ резервуаром МСК, подібних до МСК кісткового мозку, а їх концентрація В жировій тканині суттєво перевищує аналогічну в кістковому мозку. Так, в кістковому мозку дорослої людини концентрація МСК становить 1 на 50-100 тис., а в жировій тканині - 1 на 30-1000 клітин [5, 6].

Однак проблема використання МСК $є$ надзвичайно дискусійною, залишаються численні невирішені питання як в розумінні біологічних властивостей МСК, так і їх практичного застосування. Попри певні протиріччя у поглядах науковців, безпека використання МСK $\epsilon$ безперечною [7]. Важливим позитивним фактором $€$ низька імуногенність МСК у зв'язку з використанням алогенного матеріалу.

Таким чином, розбіжність поглядів щодо використання МСК при дегенеративно-дистрофічних захворюваннях опорнорухового апарату та недостатня кількість клінічних досліджень зумовлюють підвищений інтерес до вивчення методики.
Мета: оцінити функціональні результати та клінічну ефективність застосування МСК, одержаних 3 жирової тканини, при деформуючому остеоартрозі ІІ ст. протягом 12-місячного періоду спостереження.

\section{Об'єкт і методи дослідження}

Обстежено 10 пацієнтів із деформуючим остеоартрозом КС II ст.: 6 (60,0\%) чоловіків та 4 (40,0\%) жінки. Середній вік

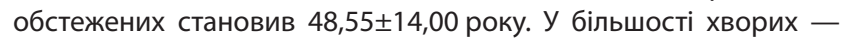
$9(90,0 \%)$ - однобічне ураження КС, у $1(10,0 \%)$ пацієнтки процес мав двобічний характер. Таким чином, проаналізовано результати обстеження $11 \mathrm{KC}$.

Лікування деформуючого остеоартрозу КС здійснювали шляхом внутрішньосуглобового введення МСК, одержаних 3 жирової тканини. Отримано добровільні інформовані згоди пацієнтів на проведення процедури.

МСК отримували 3 жирової тканини, використовуючи технологію Lipogems ${ }^{\circledast}$ («Lipogems International SpA», Італія) згідно з рекомендованою методикою. Одержання МСК здійснювали за допомогою одноразового набору для ліпоаспірації, обробки та ін'єкції очищеної жирової тканини. Ліпоаспірацію виконували за допомогою вакуумного шприца під місцевим знеболенням. Після очищення ліпоаспірату фізіологічним розчином та емульгації здійснювали внутрішньосуглобове введення отриманого препарату.

До початку лікування в усіх пацієнтів оцінювали стан КС на основі результатів об'єктивного обстеження, даних рентгенографічного дослідження та магнітно-резонансної томографії КС. Показники функціонального стану ураженого суглоба оцінювали з використанням шкали KOOS (Knee Injury and Osteoarthritis Outcome Score). Стадію остеоартрозу КС оцінювали відповідно до класифікації Kellgren - Lawrence (1957 р., зі змінами 1982 р.). Клінічну оцінку ефективності проведеної терапії здійснювали через 12 міс від моменту внутрішньосуглобового введення МСК, одержаних з жирової тканини, шляхом виконання ідентичних досліджень. У подальшому оцінювали динаміку зміни отриманих показників.

Статистичний аналіз даних проводили з використанням методів непараметричної статистики. Ймовірність безпомилкового прогнозу встановлювали на рівні $p<0,05$. Для розрахунків використовували програми «Microsoft Excel 2019» та «StatSoft STATISTICA 10». 


\section{Результати та їх обговорення}

Протягом 12-місячного періоду спостереження у хворих з II ст. гонартрозу отримано позитивну динаміку за всіма досліджуваними категоріями оцінювання функціонального стану КС (таблиця).

У віддалений період після застосування МСК, одержаних 3 жирової тканини, відмічали підвищення показника за категорією «Симптоми» на 27,87\%. Середній результат за категорією «Симптоми» при первинному зверненні пацієнтів стано-

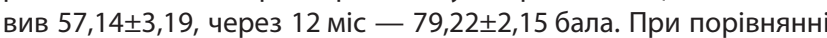
досліджуваних показників доведено достовірну відмінність між ними $(p=0,00005)$.

Протягом періоду спостереження у пацієнтів відмічали зниження больового синдрому та відповідно достовірно кращі значення за категорією «Біль». До початку лікування значен-

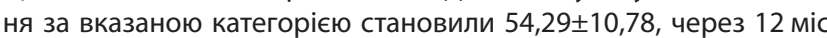

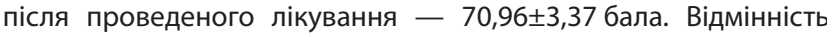
між показниками статистично значуща $(p=0,0002)$. Зафіксовано зростання вказаних показників на 23,49\%.

Таблиця Динаміка змін результатів лікування за шкалою KOOS у хворих з гонартрозом II ст.

\begin{tabular}{lccc}
\hline \multirow{2}{*}{\multicolumn{1}{c}{ Характеристика }} & \multicolumn{2}{c}{ Результати лікування } & \multirow{2}{*}{ p } \\
\cline { 2 - 3 } & Первинні & Віддалені & \\
\hline Симптоми, бали & $57,14 \pm 3,19$ & $79,22 \pm 2,15$ & $0,00005^{*}$ \\
\hline Біль, бали & $54,29 \pm 10,78$ & $70,96 \pm 3,37$ & $0,0002^{*}$ \\
\hline Функція, повсякденне життя, бали & $58,96 \pm 7,45$ & $72,73 \pm 1,52$ & $0,00007^{*}$ \\
\hline Функція, спорт та активний відпочинок, бали & $47,27 \pm 4,10$ & $66,36 \pm 5,05$ & $0,00006^{*}$ \\
\hline Якість життя, бали & $50,00 \pm 4,84$ & $73,30 \pm 5,65$ & $0,00006^{*}$ \\
\hline
\end{tabular}

*Встановлено достовірну відмінність показників при $\mathrm{p} \leq 0,05$.

Показник спроможності рухатися та піклуватися про себе, визначений за категорією «Функція, повсякденне життя», у пацієнтів 3 II ст. дегенеративно-дистрофічного ураження КС

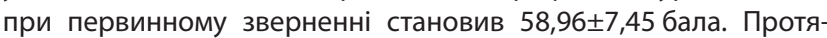
гом дослідження відмічали достовірне покращення результату за визначеною категорією, який після повторного обстеження становив $72,73 \pm 1,52$ бала $(p=0,00007)$. Після проведеного лікування зафіксовано підвищення показників, що характеризували спроможність рухатися та піклуватися про себе, на 18,93\%.

щодо показників фізичної активності обстежених пацієнтів, у віддалений період після проведеного лікування відмічали достовірно кращий результат за категорією «Функція, спорт та активний відпочинок», який до початку лікування становив $47,27 \pm 4,10$ бала,

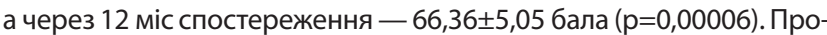
тягом дослідження виявлено зростання показника фізичної активності на 28,77\% відносно первинних результатів обстеження, отриманих до початку лікування.

Окрім того, у віддалений період вдалося досягнути покращення показника якості життя на 31,79\%. До початку лікування середній показник за категорією «Якість життя» у пацієнтів з II ст. дегенеративно-дистрофічних захворювань КС при пер-

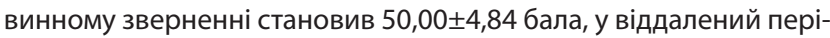

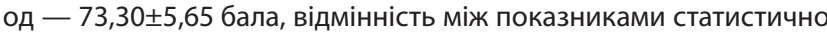
значуща $(p=0,00006)$.

\section{Висновки}

Таким чином, протягом 12-місячного періоду спостереження доведено високу клінічну ефективність застосування МСК, одержаних з жирової тканини, при деформуючому остеоартрозі II CT.

\section{Відомості про автора:}

Маммадов Лачін Алі огли - аспірант кафедри травматології та ортопедії Вінницького національного медичного університету ім. М.І. Пирогова, Вінниця, Україна.

E-mail: drlachinmammadov@gmail.com
У хворих 3 гонартрозом II ст. під впливом МСК, одержаних 3 жирової тканини, отримано позитивну динаміку за всіма категоріями оцінювання функціонального стану КС - «Симптоми» $(p=0,00005)$, «Біль» $(p=0,0002)$, «Функція, повсякденне життя» ( $\mathrm{p}=0,00007)$, «Функція, спорт та активний відпочинок» $(p=0,00006)$, «Якість життя» $(p=0,00006)$.

\section{Список використаної літератури}

1. Jones I.A., Wilson M., Togashi R. et al. (2018) A randomized, controlled study to evaluate the efficacy of intra-articular, autologous adipose tissue injections for the treatment of mild-tomoderate knee osteoarthritis compared to hyaluronic acid: a study protocol. BMC Musculoskel. Dis., 19(1): 383. doi.org/10.1186/s12891-018-2300-7.

2. Avila-Portillo L.M., Aristizabal F., Riveros A. et al. (2020) Modulation of Adipose-Derived Mesenchymal Stem/Stromal Cell Transcriptome by G-CSF Stimulation. Stem Cells Int., 2020: 9 p. doi.org/10.1155/2020/5045124.

3. Schiavone Panni A., Vasso M., Braile A. et al. (2019) Preliminary results of autologous adiposederived stem cells in early knee osteoarthritis: identification of a subpopulation with greater response. Int. Orthopaed., 43(1): 7-13. doi.org/10.1007/s00264-018-4182-6.

4. Vezzani B., Shaw I., Lesme H. et al. (2018) Higher Pericyte Content and Secretory Activity of Microfragmented Human Adipose Tissue Compared to Enzymatically Derived Stromal Vascular Fraction. Stem Cells Translat. Med., 7(12): 876-886. doi.org/10.1002/sctm.18-0051.

5. Старцева О.И.,Мельников Д.В.,Захаренко А.С. идр. (2016) Мезенхимальныестволовыеклетки жировой ткани: современный взгляд, актуальностьиперспективыпримененияв пластической хирургии. Res. Pract. Med. J., 3(3): 68-75. doi.org/10.17709/2409-2231-2016-3-3-7.

6. Ceserani V., Ferri A., Berenzi A. et al. (2016) Angiogenic and anti-inflammatory properties of micro-fragmented fat tissue and its derived mesenchymal stromal cells. Vascular cell, 8: 3 . doi.org/10.1186/s13221-016-0037-3.

7. Al-Najar M., Khalil H., Al-Ajlouni J. et al. (2017) Intra-articular injection of expanded autologous bone marrow mesenchymal cells in moderate and severe knee osteoarthritis is safe: a phase I/II study. J. Orthopaed. Surg. Res., 12(1): 190. doi.org/10.1186/s13018-017-0689-6.

\section{Efficacy of adipose tissue-derived stem cells in stage II of knee osteoarthritis}

\section{L.A. Mammadov}

National Pirogov Memorial Medical University, Vinnytsia, Ukraine

Abstract. Aim: to evaluate the functional results and clinical efficacy of adipose tissue-derived stem cells in stage II of knee osteoarthritis during a 12-month follow-up period. Materials and methods. 10 patients with stage II of knee osteoarthritis, 6 (60.0\%) men and 4 (40.0\%) women were examined, the mean age was $48.55 \pm 14.00$ years. In $9(90.0 \%)$ patients a unilateral knee osteoarthritis was established, in 1 (10.0\%) bilateral. Thus, the results of the examination of 11 knee joints were analyzed. Treatment of knee osteoarthritis was performed by intraarticular injection of adipose tissue-derived stem cells using Lipogems ${ }^{\circledast}$ technology ("Lipogems International SpA», Italy) according to the recommended technique. Clinical outcomes were assessed before treatment and 12 months after the procedure. The functional state of the knee joint was assessed using the Knee Injury and Osteoarthritis Outcome Score (KOOS). Statistical analysis was performed using «Microsoft Excel 2019" and "StatSoft STATISTICA 10». Results. In the remote period after the use of adipose tissue-derived stem cells in patients with stage II of knee osteoarthritis, positive dynamics was obtained in all categories of assessment of the functional state of the knee joints: «Symptoms» $(p=0.00005)$, «Pain» $(p=0.0002)$, «Function, everyday life» $(p=0.00007)$, «Function, sports and leisure» $(p=0.00006)$, «Quality of life» $(p=0.00006)$. Conclusion. During the 12-month follow-up period, high clinical efficacy of adipose tissue-derived stem cells in stage II of knee osteoarthritis was demonstrated.

Key words: osteoarthritis, knee joint, mesenchymal stem cells, adipose tissue.

\section{Information about the author:}

Mammadov Lachin A. — graduate student of the Department of Traumatology and Orthopedics, National Pirogov Memorial Medical University, Vinnytsia, Ukraine.

E-mail:drlachinmammadov@gmail.com 